\title{
INTENSIVE BREEDING OF MICE
}

\author{
BY W. LANE-PETTER \\ Laboratory Animals Bureau, Medical Research Council Laboratories, \\ Holly Hill, Hampstead, London, N.W. 3
}

(With 1 Figure in the Text)

In any programme of animal breeding, both the quality and quantity of the animals produced have to be considered. The quality must not fall below a certain standard, set by the requirements of the work for which the animals are to be used; and the numbers used must be reasonably predictable as well as taking into account the need for economic production. It is with the exploitation of a breeding colony in terms of numbers used that this paper will chiefly deal.

The recent history of a small mouse colony maintained at Hampstead will be used in illustration. This colony was founded in late 1949 from cross-bred coloured stock. The first selection factors applied were general vigour and a silver grey colour. Vigour has been prominent from the beginning and has been maintained throughout. The colour, once fixed by selective breeding, gave way to a second factor, high rate of production, which then moved up into first place. Analysis of records, on which selection for productivity has been based, has been of the simplest.

The colony has been random-mated within a closed population. Details of the strain, now known as 'L.A.B. Grey', have been described elsewhere (Catalogue, 1953).

\section{THE COLONY}

The present paper deals with 252 consecutive litters born from 25 March 1953 to 15 December 1954. These litters were born in 40 boxes; one litter (box 31), born to a primipara, was killed and eaten by the mother before it was counted, and has therefore been ignored. Of the remaining 39 boxes, 21 contained pairs ( $\delta$ 우), 16 contained trios ( $\delta$ 우) and two quartets ( $\delta$ 우우). With the exception of two boxes (nos. 22 and 23, both $\delta$ 우), all breeders, once mated, were left together until the box was discarded. In the case of boxes 22 and 23 , there was a short period of separation which included the period from birth to weaning of the first litters; after that they were reunited permanently. Some of the boxes were still in production at the time of writing.

\begin{tabular}{|c|c|c|c|}
\hline \multicolumn{4}{|c|}{ PRODUCTION } \\
\hline$\delta ㅇ$ & 호우우 & 주우우우 & Total \\
\hline 21 & 16 & 2 & 39 \\
\hline 114 & 111 & 26 & 251 \\
\hline 1079 & 984 & 231 & 2294 \\
\hline
\end{tabular}

In some of the boxes, where mice were born in excess of ten to a litter, or where the aggregate of two or more litters overflowed the communal nest. the numbers 
were reduced by culling. In general, these culls have been treated as if they had not been born, and the 'net number borm' $(e)$ has been used.

(d) No. of culls

(e) Net no. born $(c-d)$

(f) Average net litter-size born $(e / b)$

$(g)$ No. stillborn

(h) Stillbirth rate $(g / c)(\%)$

(i) Net stillbirth rate $(g / e)(\%)$

(j) No. weaned

(k) Weaning rate $(j / e)(\%)$

(l) Average litter-size weaned $(j / b)$

\begin{tabular}{|c|c|}
\hline б우 & 주우우 \\
\hline 24 & 29 \\
\hline 1055 & 955 \\
\hline $9 \cdot 3$ & $8 \cdot 6$ \\
\hline 7 & 15 \\
\hline $0 \cdot 65$ & 1.5 \\
\hline $0 \cdot 66$ & 1.6 \\
\hline 997 & 898 \\
\hline $94 \cdot 5$ & $94 \cdot 0$ \\
\hline $8 \cdot 8$ & $8 \cdot 1$ \\
\hline
\end{tabular}

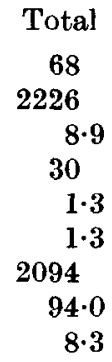

The above figures consistently show advantages for pairs over trios and for trios over quartets.

The overall productivity is not, however, only dependent on average litter-size born or weaned; it must also take into account the frequency of kindling. This is most conveniently measured by the number of days from mating to birth, or from the birth of one litter to the birth of the next, and is referred to as the 'prenatal interval'.

$(m)$ Average prenatal interval (days)

(n) No. weaned per doe per week $(l \times 7) / m$

(o) No. weaned per doe per year $(l \times 365) / m$

\begin{tabular}{|c|c|c|c|}
\hline 후우 & j우우 & 후우우우 & Total \\
\hline $30 \cdot 8$ & $36 \cdot 2$ & $35 \cdot 0$ & $33 \cdot 3$ \\
\hline $2 \cdot 0$ & $1 \cdot 6$ & 1.5 & $1 \cdot 75$ \\
\hline 104 & 82 & 80 & 91 \\
\hline
\end{tabular}

Again, the order of merit is pairs-trios-quartets. So far the evidence has been in favour of pairs, but note must also be taken of the larger number of boxes required when monogamous pairs are used rather than trios or quartets. This can be represented as the number of box days per mouse weaned:

$$
\begin{aligned}
& \text { (p) Box days per mouse weaned } \\
& \text { ๙우 } \\
& 3 \cdot 5 \\
& \text { 후우우 } \\
& 2 \cdot 3 \\
& \text { 주우우우 } \\
& 1.7
\end{aligned}
$$

There is also the question of feeding extra males in the case of pairs and trios, measured by the number of days it is necessary to keep an adult breeder, male or female, for every mouse weaned:
$(q)$ Breeder days per mouse weaned
$7 \cdot 1$
$7 \cdot 7$
$8 \cdot 7$

30

주우우

주우우우

For a given output, about twice as many boxes are needed for monogamous pairs as for quartets $(p)$, but this is slightly compensated by an $18 \%$ saving in feeding $(q)$, for the lower productivity of quartets is not enough to compensate for the fact that three-quarters of the quartet population is female and litter-bearing, while only half the pair population is so. In both instances trios show intermediate figures.

\section{SEASONAL VARIATIONS IN PRODUCTIVITY}

Many mouse colonies show some seasonal variation in reproductive performance, and this colony was no exception. Figures for the 12 months of the year are shown in Table 1, in relation to pairs only. The chief point of interest emerging from study of these figures was that there was a direct relation between litter-size and prenatal 
interval, which tended to cancel out, so that the overall productivity remained steady throughout the year. There does not appear to be any relation between litter-size and weaning rate; this is in agreement with Bruce's findings (1947).

\section{Table 1}

\begin{tabular}{|c|c|c|c|c|c|c|c|c|c|c|c|c|c|}
\hline $\begin{array}{c}\text { Pairs only } \\
\text { No. of litters born }\end{array}$ & $\begin{array}{c}\text { Jan. } \\
2\end{array}$ & $\begin{array}{c}\text { Feb. } \\
5\end{array}$ & $\begin{array}{l}\text { Mar. } \\
4\end{array}$ & $\begin{array}{l}\text { Apr. } \\
6\end{array}$ & $\begin{array}{l}\text { May } \\
11\end{array}$ & $\begin{array}{l}\text { June } \\
10\end{array}$ & $\begin{array}{l}\text { July } \\
14\end{array}$ & $\begin{array}{l}\text { Aug. } \\
12\end{array}$ & $\begin{array}{l}\text { Sept. } \\
12\end{array}$ & $\begin{array}{l}\text { Oct. } \\
14\end{array}$ & $\begin{array}{l}\text { Nov. } \\
\text { Il }\end{array}$ & $\begin{array}{l}\text { Dec. } \\
8\end{array}$ & $\begin{array}{l}\text { Tot. } \\
114\end{array}$ \\
\hline $\begin{array}{l}\text { Average size of } \\
\text { litters born* }\end{array}$ & $15 \cdot 5$ & $11 \cdot 8$ & $10 \cdot 0$ & $10 \cdot 5$ & $9 \cdot 0$ & 8.9 & $8 \cdot 0$ & $9 \cdot 2$ & $7 \cdot 6$ & $9 \cdot 2$ & $9 \cdot 4$ & $9 \cdot 9$ & 9 . \\
\hline $\begin{array}{l}\text { Average size of } \\
\text { litters weaned }\end{array}$ & $14 \cdot 0$ & $11 \cdot 4$ & $9 \cdot 7$ & $10 \cdot 0$ & $8 \cdot 4$ & $8 \cdot 3$ & $7 \cdot 6$ & $8 \cdot 8$ & $7 \cdot 1$ & 8.9 & $9 \cdot 1$ & $9 \cdot 0$ & 8. \\
\hline Weaning rate $(\%)$ & 90 & 97 & 97 & 95 & 93 & 93 & 95 & 96 & 93 & 97 & 97 & 91 & 94. \\
\hline $\begin{array}{l}\text { Prenatal interval } \\
\text { (days) }\end{array}$ & $43 \cdot 5$ & $39 \cdot 4$ & $40 \cdot 7$ & 26.5 & $27 \cdot 1$ & $26 \cdot 7$ & $28 \cdot 9$ & $22 \cdot 0$ & $32 \cdot 1$ & $29 \cdot 4$ & $29 \cdot 6$ & $34 \cdot 1$ & 30 \\
\hline $\begin{array}{l}\text { Box/days per } \\
\text { mouse weaned }\end{array}$ & $3 \cdot 1$ & $3 \cdot 5$ & $4 \cdot 2$ & $2 \cdot 8$ & $3 \cdot 3$ & $3 \cdot 2$ & $3 \cdot 8$ & $2 \cdot 5$ & $4 \cdot 5$ & $3 \cdot 3$ & $3 \cdot 3$ & $3 \cdot 8$ & $3 \cdot$ \\
\hline $\begin{array}{l}\text { Mice weaned per } \\
\text { doe per week }\end{array}$ & $2 \cdot 3$ & $2 \cdot 0$ & $1 \cdot 7$ & $2 \cdot 5$ & $2 \cdot 1$ & $2 \cdot 2$ & 1.9 & $2 \cdot 8$ & $1 \cdot 6$ & $2 \cdot 1$ & $2 \cdot 1$ & $1 \cdot 9$ & $2 \cdot 1$ \\
\hline
\end{tabular}

\section{SELECTION FOR MAXIMUM PRODUCTIVITY}

It is reasonable to expect that, especially in a heterozygous stock such as this one, selective breeding will result in an increased productivity, eventually reaching a maximum. If this is so, it will be necessary to continue the same process of selection of breeding stock if the maximum is to be maintained. Whatever other characteristics may be considered desirable for selective breeding, productivity will nearly always be an important one. Falconer (1952) discussed the principles of such improvement, and the observance of these principles has resulted in the high productivity shown by this colony.

Criteria for selection of breeding stock have been: (i) a stillbirth rate below a certain arbitrary figure; (ii) a weaning rate above a certain arbitrary figure; (iii) a low value for prenatal days per mouse weaned, $Q$, sustained for successive litters.

In order that these criteria can be correctly evaluated, a record card should be kept for each breeding female. Such a card is illustrated (Fig. 1). The keeping of records of this kind is simple; indeed, it represents the minimum recording of breeding performance that is acceptable in any colony. The keeping of accurate records, and the application of selection for future breeding, is easier when pairs, rather than trios or quartets, are maintained together; and when intensive selection for improvement, along the lines suggested by Falconer (1952) is practised, this advantage may outweigh the rather lower overall productivity per box (see Bruce, 1954). It may also be possible to use smaller boxes for pairs than for larger groups and this also reduces the advantage possessed by the latter in economy of shelf space.

About a year before the beginning of the observations considered in this paper the average litter-size in this colony was 10 . The colony was then reduced to very small numbers, and in consequence the field of selection was narrowed. It was for this reason that the average litter-size regressed. An examination of the performances of different boxes shows that both litter-size, and also the quotient $Q$ 
of prenatal days by mice born and subsequently weaned (viable births), varied within wide limits. Average litter-size varied from box to box between $5 \cdot 3$ and $13 \cdot 0$, and the figure for $Q$ from $2 \cdot 6$ to $8 \cdot 0$. These great differences give a wide field for selection, and with proper record keeping and analysis can be easily exploited.

\begin{tabular}{|c|c|c|c|c|c|c|c|}
\hline \multicolumn{3}{|l|}{ Box no. } & \multicolumn{3}{|c|}{ of from } & Born & Wt. \\
\hline \multicolumn{3}{|c|}{ Date made up } & \multicolumn{3}{|c|}{ of from } & Born & Wt. \\
\hline \multicolumn{8}{|c|}{ Index no. } \\
\hline $\begin{array}{l}\text { Date of } \\
\text { birth }\end{array}$ & No. & $\begin{array}{l}\text { Still- } \\
\text { born }\end{array}$ & $\begin{array}{l}\text { Date of } \\
\text { weaning }\end{array}$ & No. & Av. wt. & $Q$ & Remarks \\
\hline & & & & & & & \\
\hline & & & & & & & \\
\hline & & & & & & & \\
\hline & & & & & & & \\
\hline & & & & & & & \\
\hline & & & & & & & \\
\hline & & & & & & & \\
\hline & & & & & & & \\
\hline & & & & & & & \\
\hline & & & & & & & \\
\hline & & & & & & & \\
\hline & & & & & & & \\
\hline
\end{tabular}

Fig. 1. Record card for a permanently mated pair.

There was no evidence in this strain that the figure for $Q$ tended to rise with parity, at least up to ten or twelve litters from a single doe. Does were discarded on account of age (a breeding life of some 10 months or so, no matter how many litters are born in that time, is enough) or because they were consistently well below average in productivity; or for some other reason.

It was also found that the value of $Q$ calculated after the first two or three litters is in nearly all cases very close to the final value of $Q$ after ten or more litters, as is shown in Table 2, which gives figures for a typical good pair. This indicates that families of high productivity can be recognized early in their breeding life, and those of low productivity early discarded.

Table 2. Box no. 26

$\begin{array}{lccccccccccc}\text { Parity _.. } & 1 & 2 & 3 & 4 & 5 & 6 & 7 & 8 & 9 & 10 & 11 \\ \text { Prenatal days } & 22 & 65 & 107 & 131 & 154 & 176 & 198 & 224 & 246 & 263 & 292 \\ \text { Viable births } & 10 & 21 & 30 & 39 & 48 & 58 & 68 & 77 & 84 & 92 & 98 \\ Q & 2 \cdot 2 & 3 \cdot 1 & 3 \cdot 6 & 3 \cdot 4 & 3 \cdot 2 & 3 \cdot 0 & 2 \cdot 9 & 2 \cdot 9 & 2 \cdot 9 & 2 \cdot 9 & 3 \cdot 0\end{array}$




\section{DISCUSSION}

Unless selection for improvement is constantly practised on sound lines, the productivity of a mouse colony will be far below its potential. The picking out of 'nice-looking' animals for future breeding stock does not represent a sound policy; on the other hand, extensive statistical calculations are not usually necessary. Simple record keeping, regularly analysed, will enable the most productive stock to be recognized so that their progeny can be saved for breeding. The cost of breeding animals is closely related to their productivity, and many heterozygous stocks are probably capable of marked improvement by selection which will result in considerable savings in cost of production.

The same records will enable accurate predictions of output to be made, and this will to some extent mitigate the situation arising when either there are not enough animals, or there are too many and the surplus has to be killed.

A current knowledge of stillbirth and weaning rates is also desirable, for any sudden alteration in either may herald trouble in the colony, in time for steps to be taken to eliminate it.

It is reasonably certain that the present productivity of this colony, though high, is capable of further improvement, in view of the great variation in the value of $Q$ from box to box.

\section{SUMMARY}

1. Production figures are given for a small mouse colony.

2. High productivity depends upon careful selection of breeding stock.

3. This selection has been based on an analysis of individual records. Both the keeping and the analysis of records are easy and simple.

4. In addition to providing a basis for selection, these records make possible a forecast of future production.

I particularly wish to thank Miss D. Lawrence, the animal technician whose skill in looking after this colony has contributed so much to its successful performance.

\section{REFERENCES}

Bruce, H. M. (1947). J. Hyg., Camb., 45, 420.

Bruce, H. M. (1954). J. Hyg., Camb., 52, 60.

Carter, T. C. (1951). J. Anim. Tech. Ass. 1, no. 4, 2.

Catalogue (1953). Catalogue of uniform strains of Laboratory animals (Laboratory Animals Bureau).

Falconer, D. S. (1952). J. Anim. Tech. Ass. 3, no. 1, 9.

(MS. received for publication 14. II. 55) 